\title{
Quantification of the tidal stream exergy in the ría de Vigo (NW Spain)
}

\section{Marc Mestres*}

International Centre for Coastal Resources Research (CIIRC),

c/ Jordi Girona 1-3, Mòdul D1,

Barcelona, 08034, Spain

and

Laboratori d'Enginyeria Marítima (LIM-UPC),

Universitat Politècnica de Catalunya-BarcelonaTech,

c/ Jordi Girona 1-3, Mòdul D1,

Barcelona, 08034, Spain

Fax: +34 934011861

Email: mmestresridge@gmail.com

${ }^{*}$ Corresponding author

\section{Maria Griñó}

Laboratori d'Enginyeria Marítima (LIM-UPC),

Universitat Politècnica de Catalunya-BarcelonaTech,

c/ Jordi Girona 1-3, Mòdul D1,

08034 Barcelona, Spain

Email: m.grino.colom@gmail.com

\section{Joan Pau Sierra and César Mösso}

International Centre for Coastal Resources Research (CIIRC), c/ Jordi Girona 1-3, Mòdul D1,

Barcelona, 08034, Spain

and

Laboratori d'Enginyeria Marítima (LIM-UPC),

Universitat Politècnica de Catalunya-BarcelonaTech,

c/ Jordi Girona 1-3, Mòdul D1,

Barcelona, 08034, Spain

Email: joan.pau.sierra@upc.edu

Email: cesar.mosso@upc.edu

\begin{abstract}
The exergy of the tidal currents in the ría de Vigo area (NW Spain) is quantified using the results of a 28-day long simulation of the tidal flows. The results show that the northernmost strait connecting the ría with the Atlantic Ocean is a promising site for tidal energy tapping, in contrast with the energetically weaker estuary. On the basis of the average power density (APD), a $7.5 \mathrm{~km}^{2}$ region is identified in this strait as the most advantageous area to install tidal energy converters (TECs), with a total annual exergy of around
\end{abstract}


$3865 \mathrm{MWh} / \mathrm{m}^{2}$. Similar analyses using only 14-day simulations change this value in $\pm 16 \%$, depending on whether the tidal cycle considered is apogean or perigean. The study contributes to enlarge the inventory of sites along the NW Spanish coast at which tidal stream energy can be potentially extracted.

Keywords: ría de Vigo; tidal current exergy; mesotidal estuary; numerical modelling; ROMS_AGRIF.

Reference to this paper should be made as follows: Mestres, M., Griñó, M., Sierra, J.P. and Mösso, C. (xxxx) 'Quantification of the tidal stream exergy in the ría de Vigo (NW Spain)', Int. J. Exergy, Vol. x, No. x, pp.xxx-xxx.

Biographical notes: Marc Mestres is a Researcher with over 20 years experience in the Numerical Modelling of Coastal Hydrodynamics and Dispersion. He holds a PhD in Physics (UPC, 2002), and has taken part in many publicly funded research projects. He has published over 25 papers in peer-reviewed journals, more than 40 contributions to scientific conferences and meetings and 24 technical and research reports.

Maria Griñó is a Civil Engineer specialised in Water Engineering and Renewable Energies. She obtained her Master's degree at the Universitat Politècnica de Catalunya - BarcelonaTech in 2015, and is currently a Project Coordinator at OCA Chile.

Joan Pau Sierra is a $\mathrm{PhD}$ in Civil Engineering, and Full Professor at the Universitat Politècnica de Catalunya (UPC). He develops his research activity in the field of Coastal Engineering, in particular in the study of physical processes and numerical modelling of hydrodynamics in coastal areas. He has published more than 60 research papers in SCI journals, more than 170 communications in conferences and workshops and 120 technical and research reports. He has supervised $12 \mathrm{PhD}$ theses, six MSc theses and 60 graduation theses.

César Mösso received his PhD in Marine Sciences at Universitat Politècnica de Catalunya (UPC), and is an Associate Professor in the Department of Civil and Environmental Engineering (DECA). His research is focused essentially on the field of maritime engineering, and his current activity is centred on the data analysis of coastal and harbour hydrodynamics, and issues related to climate change and the related impacts in the coastal zone.

\section{Introduction}

Within the global context of growing energy demand, decreasing reservoirs of conventional fossil fuels and rising environmental awareness, focus has shifted towards the production of sustainable energy. Numerous studies have been devoted in the last two decades to assess the exergy of different potential sources of energy, such as solar radiation (Edalati et al., 2016; Kurtgoz and Deniz, 2016), wind (Öztürk, 2011) or the various marine options (Bryden et al., 2007; Miguel and Aydin, 2012; Liberti et al., 2013). In this sense, tidal currents appear to be one of the most promising sources for green energy (O'Rourke et al., 2010). Although the principles behind wind and tidal power extraction are essentially the same, there are some factors that favour the latter, 
among them the high predictability of tidal currents as compared to atmospheric flows, or the minimum environmental impact associated to tidal energy-extracting facilities (Iglesias et al., 2012). In addition, the higher density of seawater (over 800 times that of air) guarantees that, for typical fluid speeds and under equal extracting conditions (i.e., cross-sectional area), the power generated by a tidal energy converter (TEC) will be comparable to that generated by a wind energy converter.

Recently, tidal exergy has been evaluated at different coastal regions, using either extensive field campaigns or numerical modelling, as a first step towards identifying suitable locations for tidal stream exploitation and to quantify the level or energy that can be extracted. Some examples include the UK (Draper et al., 2014; Xia et al., 2010), the USA (Brooks, 2011), Canada (Karsten et al., 2008) or Norway (Grabbe et al., 2009), but also the coasts of developing countries such as Iran (Rashid, 2012) or China (Li et al., 2010).

In the particular case of Spain, renewable sources provide $14.4 \%$ of the primary energy that is used (APPA, 2015), and one-third of the electricity produced (APPA, 2016). Of the latter, $90 \%$ is provided by wind, hydraulic and solar sources (MINETUR, 2014). Nevertheless, in the last few years the interest in marine sources of energy has increased considerably. Most of it has been focused on wave exergy (e.g., Iglesias and Carballo, 2005; Sierra et al., 2013), but tidal energy resources have also been evaluated at several sites along the Spanish coast (Carballo et al., 2009; Mösso et al., 2015).

With the goal of contributing to the map of sites for potentially exploitable tidal current energy, in this paper we assess the exergetic potential of the tidal stream in the ría de Vigo area, in the Northwest Spanish Atlantic coast. For this, we use the results of a 28-day numerical simulation employing a previously validated 3D hydrodynamic model. The analysis allows identifying the area in which the available tidal exergy is the largest and is, thus, the most appropriate theoretical location for the development of a TEC plant.

\section{Study area}

The ría de Vigo (Figure 1) is the southernmost of the four rías Baixas, located in the Northwestern Spanish Atlantic coast. It stretches approximately $32 \mathrm{~km}$ in a rough NE-SW direction, with an external width of $10 \mathrm{~km}$ and a depth in its central part of about $26 \mathrm{~m}$, which decreases rapidly towards the banks (Martín, 2003). This ría covers an area of about $185 \mathrm{~km}^{2}$, and has a volume capacity slightly larger than $3250 \mathrm{Hm}^{3}$, yielding a surface/volume ratio of 0.05, typical of V-shaped estuaries (Nogueira et al., 1997). The waterbody is connected to the Atlantic Ocean through three channels defined by the presence of the Cíes Islands at the estuary mouth. The northern channel is around $2.5 \mathrm{~km}$ wide, with a maximum depth of $23 \mathrm{~m}$, while the southern mouth is wider and deeper ( $5 \mathrm{~km}$ and $52 \mathrm{~m}$, respectively), and the central channel, separating both islands, is narrower and shallow (Montero, 1999).

Astronomical tides constitute the principal contribution to the sea level variations in this area. The tidal wave propagation along the ría is synchronic, at least downstream from the Rande Strait, showing no significant gradients neither in amplitude nor in phase. The tidal range varies between $0.82 \mathrm{~m}$ and $4.21 \mathrm{~m}$, with a mean value of $2.4 \mathrm{~m}$. Sea level variations associated to storm surge are typically much smaller, although values of -1.08 and $0.69 \mathrm{~m}$ have been observed during the 1992-2009 period (Álvarez et al., 2005). 
Figure 1 Map of the study area, and its location in the NW Spanish coast. The dashed line shows the local computational domain used for the analyses in this study (see online version for colours)

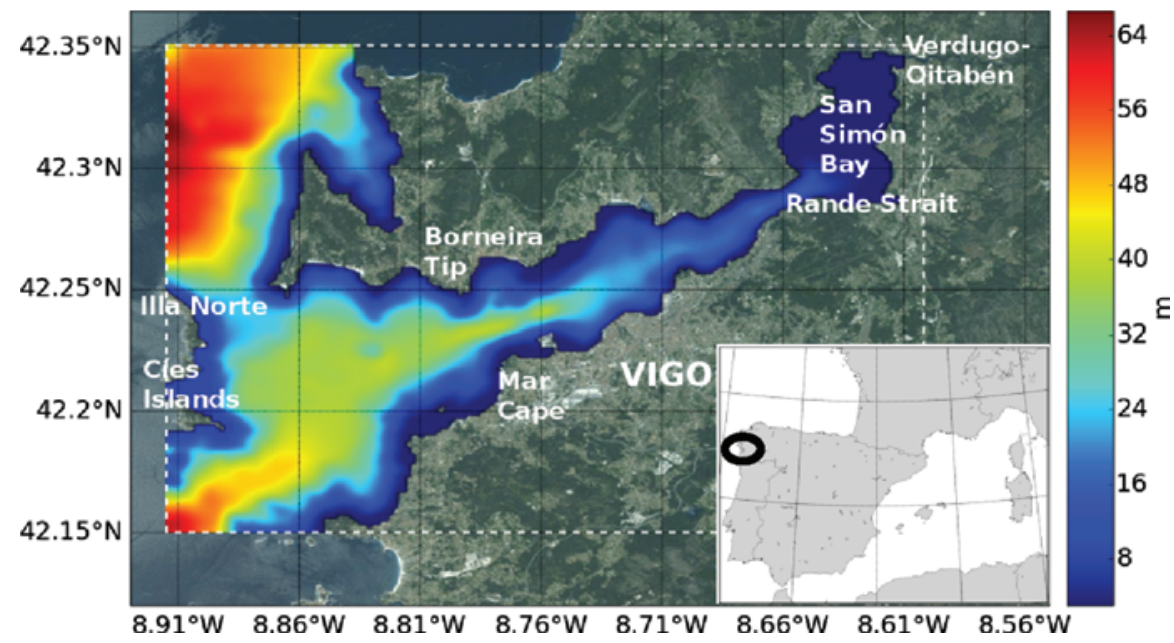

The semidiurnal mesotides also condition the circulation patterns in the estuary (Mestres and Sierra, 2011), together with the wind regimes on the continental shelf and in the ría itself, and the freshwater discharge of the Oitabén-Verdugo river system. The latter, however, is relatively low, with a mean annual discharge of $11 \mathrm{~m}^{3} / \mathrm{s}$ (Martín, 2003), and maximum monthly mean values ranging between $56 \mathrm{~m}^{3} / \mathrm{s}$ and $12.5 \mathrm{~m}^{3} / \mathrm{s}$. The residual circulation is also affected, mainly during the summer, by frequent upwelling events (Martín, 2003). The relative combination of the various forcing mechanisms allows to define three different regions from a hydrodynamic point of view. The shallow and wide basin at the estuary head is dominated by riverine output and currents induced both by the tide and the local wind. The area closest to the mouth (between the Cíes Islands and the line joining Mar Cape and Borneira Tip) is influenced mostly by tidal currents and flows driven by the wind blowing over the continental shelf, whereas the currents in the central stretch might be driven by any or all of the aforementioned forcings. Observations in the ría show that the tide is the main driver for water currents, particularly in the deeper layers in which the influence of the wind is not so important (Martín, 2003). Near the surface, the effect of the local wind becomes significant, accounting for up to $94 \%$ of the current variability. Surface flows measured in the ría are typically between 0.3 and $0.8 \mathrm{~m} / \mathrm{s}$, but can locally exceed $1.25 \mathrm{~m} / \mathrm{s}$; in the bottom layers, these currents are weaker, ranging from $0.06 \mathrm{~m} / \mathrm{s}$ to $0.15 \mathrm{~m} / \mathrm{s}$ (Martín, 2003).

\section{Methodology}

The tidal stream exergy for the ría de Vigo has been estimated from the results of a 28-day numerical simulation using a 3D hydrodynamic model forced at the boundaries exclusively by tidal sea levels and currents. The vertically integrated velocity thus obtained has then been used to assess the power densities using the equations described below. Whereas previous numerical studies have typically used a representative spring-neap tidal cycle (i.e., 14 days) to account for the corresponding tidal current 
variation, Byun et al. (2013) point out that at least a lunar month (28 days) should be considered to avoid misestimating the mean annual energy by neglecting the effects of the changes in the Earth-Moon distance. In their study of tidal energy resources in Korea, they found that the annual energy potential could be under- or overestimated by as much as $12 \%$, depending on whether the selected 14-day cycle represented an apogean or perigean tide.

\subsection{The numerical model}

The simulation of the tidally-induced currents at the ría de Vigo was carried out using the AGRIF version of the ROMS system (Regional Ocean Modelling System). It is a 3D, free-surface, terrain-following numerical model that solves the Reynolds-averaged Navier-Stokes equations using the hydrostatic and Boussinesq assumptions (Shchepetkin and McWilliams, 2005). ROMS uses the Arakawa-C differencing scheme to discretise the horizontal grid in curvilinear orthogonal coordinates, and finite difference approximations on vertical stretched coordinates (Haidvogel et al., 2008). The model follows a split-explicit approach in which the evolution of the barotropic (i.e., free surface and $2 \mathrm{DH}$ velocities) and baroclinic (temperature, salinity and 3D momentum) terms are solved separately, using different time steps. This technique considerably reduces the duration of the simulations, without affecting the validity of the solutions. The numerical details of ROMS are described extensively in Shchepetkin and McWilliams (2005).

The AGRIF version of ROMS (Penven et al., 2006) was chosen to take advantage of the set of pre- and post-processing routines, contained in the ROMS TOOLS package (Penven et al., 2007), which facilitates the preparation of the input files. Both the ROMS and ROMS_AGRIF models have been successfully applied in a variety of different scenarios with varying spatial scales (Kim and Lim, 2009; Mestres et al., 2010, 2014; Warner et al., 2005).

Cerralbo et al. (2013) implemented the ROMS_AGRIF model in the domain marked in Figure 1 using a $176 \times 153$ mesh, with a horizontal resolution of $150 \mathrm{~m}$ and 10 sigma-layers in the vertical direction. They nested this local domain in a larger mesh with hydrodynamic data obtained by the Galician Meteorological Service (Meteogalicia) using the MOHID model. Flather and Orlanski conditions were prescribed for the 2D and $3 \mathrm{D}$ variables, respectively, at the open boundaries. The horizontal diffusion was replicated using the Laplacian scheme described in Song and Haidvogel (1994), while the LMD-KPP closure scheme was used for vertical mixing (Large et al., 1994).

This implementation was validated using tidal gauge data, currents from a HF-Radar and a Horizontal Acoustic Doppler Current Profiler, and several CTD profiles within the estuary. These authors found that the model reproduced acceptably well the observed sea level variations and the surface currents (with root-mean-square errors between 0.07 and $0.13 \mathrm{~m}$ for the former, and around $0.07 \mathrm{~m} / \mathrm{s}$ for the latter), whereas it showed some larger errors for the salinity profiles, which they associated to inaccuracies in the freshwater inputs. Overall, they concluded that their implementation replicated the hydrodynamic behaviour in the ría de Vigo to an acceptable degree.

For the purpose of this study, some simplifications have been introduced in Cerralbo et al.'s (2013) approach. Density-driven flows have been disregarded by considering a constant and uniform water density of $1025 \mathrm{~kg} / \mathrm{m}^{3}$, obtained from typical observational 
values, and suppressing river discharges at the head of the estuary. Wind-induced effects have also been ignored, setting a zero wind speed throughout the simulated period. The model is then forced exclusively by tidal elevations and currents, obtained from the TPXO7.2 global model database (Egbert and Erofeeva, 2002). Comparison of the TPXO7.2 tidal parameters with those from other databases such as the LEGOS FES2004 (Lefevre et al., 2002) or the North Atlantic (AO) OTIS regional model, shows errors of the order of $1 \%$, mostly in the minor tidal constituents, indicating that the tidal forcing is well specified. The code has been run for a complete 28-day tidal month, using barotropic and baroclinic timesteps of 2 and $18 \mathrm{~s}$, respectively, and providing hourly information on the sea level and the 2DH and 3D current velocities inside the domain.

\subsection{Estimation of the potential tidal stream exergy}

The exergy of a flow of matter (air or water, for instance) can be defined as the maximum work that can be acquired when the matter flows from its original state to that of the ambient (Sahin et al., 2006). This is equivalent to the energy resource, i.e., the amount of energy (theoretically) available to be exploited (Dincer and Rosen, 2007). In the particular case of turbines placed in a flow, the energy that can be actually extracted will depend essentially on the kinetic energy of the flow and on the overall performance of the turbine. The latter variable is a measure of the exergy that is lost during the energy conversion process due to, among others, the mechanical functioning of the device. The exergetic balance during the full transformation process is given by

$$
\Delta E x=\Delta K+\Delta H+\Delta S
$$

where $\Delta K, \Delta H$ and $\Delta S$ are the changes in the system's kinetic energy, enthalpy and entropy, respectively. Their detailed expressions depend on the difference in magnitude of some flow parameters (flow speed, temperature and pressure) up- and downstream from the turbine, and can be found in Sahin et al. (2006) or Hogerwaard and Dincer (2014).

Since the goal of this study is to evaluate the potentially exploitable tidal stream resource, it is assumed hereinafter that there are no exergetic losses during the energy transformation process. A further analysis considering the effects of several factors, such as turbine performance, on the power output from a series of turbines is presented in Mestres et al. (2016).

According to Hogerwaard and Dincer (2014, cited in Mousavi, 2012), the optimum power output of a turbine can be defined as the kinetic energy of a fluid in a stream tube with a diameter equal to that of the turbine rotor, i.e.,

$$
P=C_{p} \frac{1}{2} \rho A V^{3}
$$

where $P$ is the total power output from the TEC (W), $\rho\left(\mathrm{kg} / \mathrm{m}^{3}\right)$ is the density of the fluid, $A\left(\mathrm{~m}^{2}\right)$ is the cross-sectional area of the TEC's rotor blades and $V(\mathrm{~m} / \mathrm{s})$ is the flow velocity averaged over this area. The power coefficient $C_{p}$ is introduced to account for the loss in generated power relative to the theoretically available power due to several factors. These might include turbine specifics (i.e., vertical or horizontal axis turbine, performance), the pitch angle of the blades of the turbine (Bahaj et al., 2007), the relative 
position of the turbine within an array plant deployment (Blunden and Bahaj, 2007) or the variability of the incident flow speed. Although the maximum theoretical value for $C_{p}$ is given by Betz's limit (0.59 - which can nevertheless be exceeded under certain conditions; Vennell, 2013), in practice the accepted values for tidal stream turbines range between 0.3 and 0.5 (Batten et al., 2007; Vennell, 2013).

From this equation, the power potentially accessible to a TEC can be obtained by setting $C_{p}=1$. Thus,

$$
P=\frac{1}{2} \rho A V^{3}
$$

For TECs, the average power density (APD) during one tidal cycle, in $\mathrm{W} / \mathrm{m}^{2}$ can be obtained using the output from a hydrodynamic numerical simulation, as

$$
\mathrm{APD}=\frac{1}{2} \frac{1}{N} \rho \sum_{i=1}^{N}\left(V_{i}^{3}\right)
$$

where $V_{i}(i=1, \ldots, N)$ is the velocity at time $t_{i}$ of the modelled time series, and $N$ is the number of data values.

\section{Results and discussion}

Because of the simplifications introduced into the model (no wind forcing, no density currents) a direct validation of the simulation results with observational data is not feasible. However, as mentioned before, the implementation used herein has been acceptably validated by Cerralbo et al. (2013), and the results obtained show an acceptable agreement (in both circulation patterns and magnitudes) with other studies around the same area published in the literature (e.g., Montero, 1999). As an example, the mean values of the currents obtained in this work are of the same order $(60-70 \mathrm{~cm} / \mathrm{s})$ as the surface currents measured by a high-frequency radar and used in Piedracoba et al. (2016). This allows placing some confidence on the reliability of the obtained numerical results.

The output from the ROMS_AGRIF model shows that, in general, the highest velocities in the domain are not found within the estuary, but rather in the northern channel separating the estuary from the Atlantic Ocean (Figure 2), between the largest of the Cíes islands (Monteagudo or Illa Norte) and the mainland. In this section, the tidal flow becomes accelerated due to the narrowing of the basin, during both the flood and ebb phases of the tide. Inside the ría, maximum flow velocities are of the order of $1 \mathrm{~m} / \mathrm{s}$, barely exceeding the threshold above which the currents contain enough energy for practical extraction (Myers and Bahaj, 2005).

On the other hand, the maximum flow speeds in the northern channel are much larger. At mid-flood during the spring tide, currents near the tip of the peninsula are close to $2.5 \mathrm{~m} / \mathrm{s}$, and are slightly weaker at mid-ebb $(2.2 \mathrm{~m} / \mathrm{s})$, indicating a flood-dominated ebb-flood asymmetry in the tidal flow. Note that the positions at which the maximum values of the current are attained at mid-flood and mid-ebb (PF and PE in Figure 2) are not the same, but are separated by about $1 \mathrm{~km}$ in the latitudinal direction. 
Figure 2 Barotropic currents in the domain at mid-flood (top) and mid-ebb (bottom) during a spring tide. PF and PE show the positions at which the current speed is maximum at mid-flood and mid-ebb, respectively (see online version for colours)

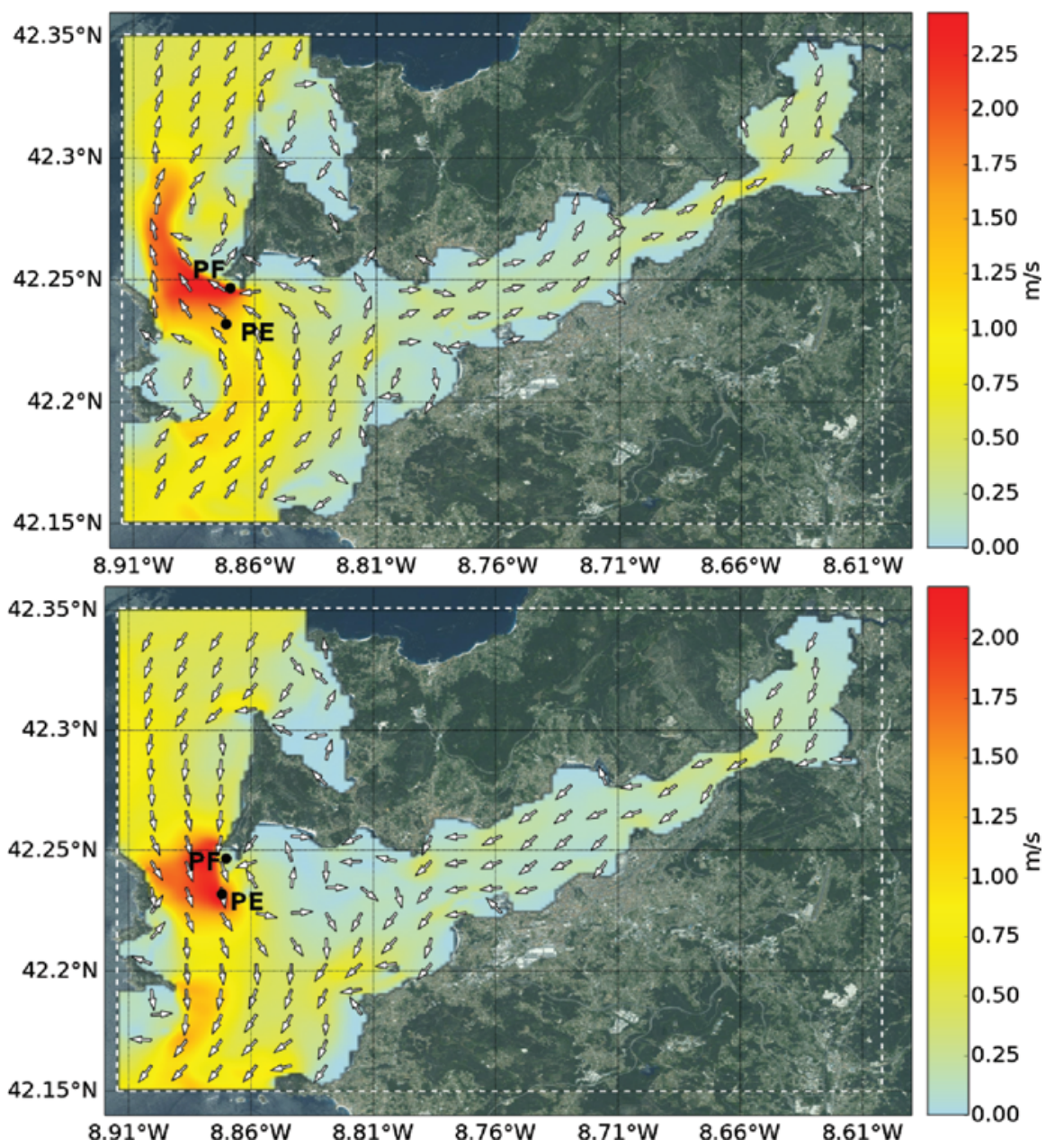

Figure 3 (top) shows the modelled time series of depth-averaged current velocity at both positions, during the complete 28 -day cycle. For both cases, the maximum modelled velocities are larger than the limit of $1.5-2 \mathrm{~m} / \mathrm{s}$ for the mean spring peak tidal current proposed by Xia et al. (2010) for the tidal stream power to be worth exploiting. According to the velocity distributions in Figure 3 (bottom) at both locations the current exceeds $1 \mathrm{~m} / \mathrm{s}$ just over one third of the time (35\% and $34 \%$, respectively). Using these velocity values, the power density for both semidiurnal cycles (mid-flood and mid-ebb of a mean spring tide) can be calculated using equation (3), yielding a maximum peak value of $7.5 \mathrm{~kW} / \mathrm{m}^{2}$ during the flood and $5.6 \mathrm{~kW} / \mathrm{m}^{2}$ during the ebb (Figure 4).

The APD during the full simulated period can be calculated from equation (4) using the flow speed time series at each computational node. The resulting distribution (Figure 5) reveals that, although the largest values of APD are again found in the northern channel, the highest APD does not correspond to neither of the nodes with higher peak 
currents (PF and PE), but to a position slightly to the west of PF (PM in Figure 5). At this point, the APD is $1.67 \mathrm{~kW} / \mathrm{m}^{2}$, which is significantly larger than the values estimated at $\mathrm{PF}\left(0.96 \mathrm{~kW} / \mathrm{m}^{2}\right)$ and $\mathrm{PE}\left(0.71 \mathrm{~kW} / \mathrm{m}^{2}\right)$. The time variation of the power density at PF and PE, calculated using the current series given in Figure 3 (top), is shown in Figure 6. The total energy available for extraction at these points during both modelled tidal cycles is the area under the curves. The estimated energy densities for the simulated period at PF and $\mathrm{PE}$ are $647.63 \mathrm{kWh} / \mathrm{m}^{2}$ and $478.71 \mathrm{kWh} / \mathrm{m}^{2}$, respectively, which correspond to an annual energy density of $8.44 \mathrm{MWh} / \mathrm{m}^{2}$ and $6.24 \mathrm{MWh} / \mathrm{m}^{2}$. A similar integration at PM yields considerably higher energy densities, about $1122.24 \mathrm{kWh} / \mathrm{m}^{2}$ for the simulated period and around $14.64 \mathrm{MWh} / \mathrm{m}^{2}$ for an entire year. At all three points, the available energy associated to the tidal stream is larger than the maximum value found by Carballo et al. (2009) in the nearby ría de Muros $\left(5.3 \mathrm{MWh} / \mathrm{m}^{2}\right)$.

Figure 3 (Top) Current speed modelled at positions PF (a) and PE (b) during the tidal month. (Bottom) Histogram of modelled velocity distribution at PF (left) and PE (right) (see online version for colours)
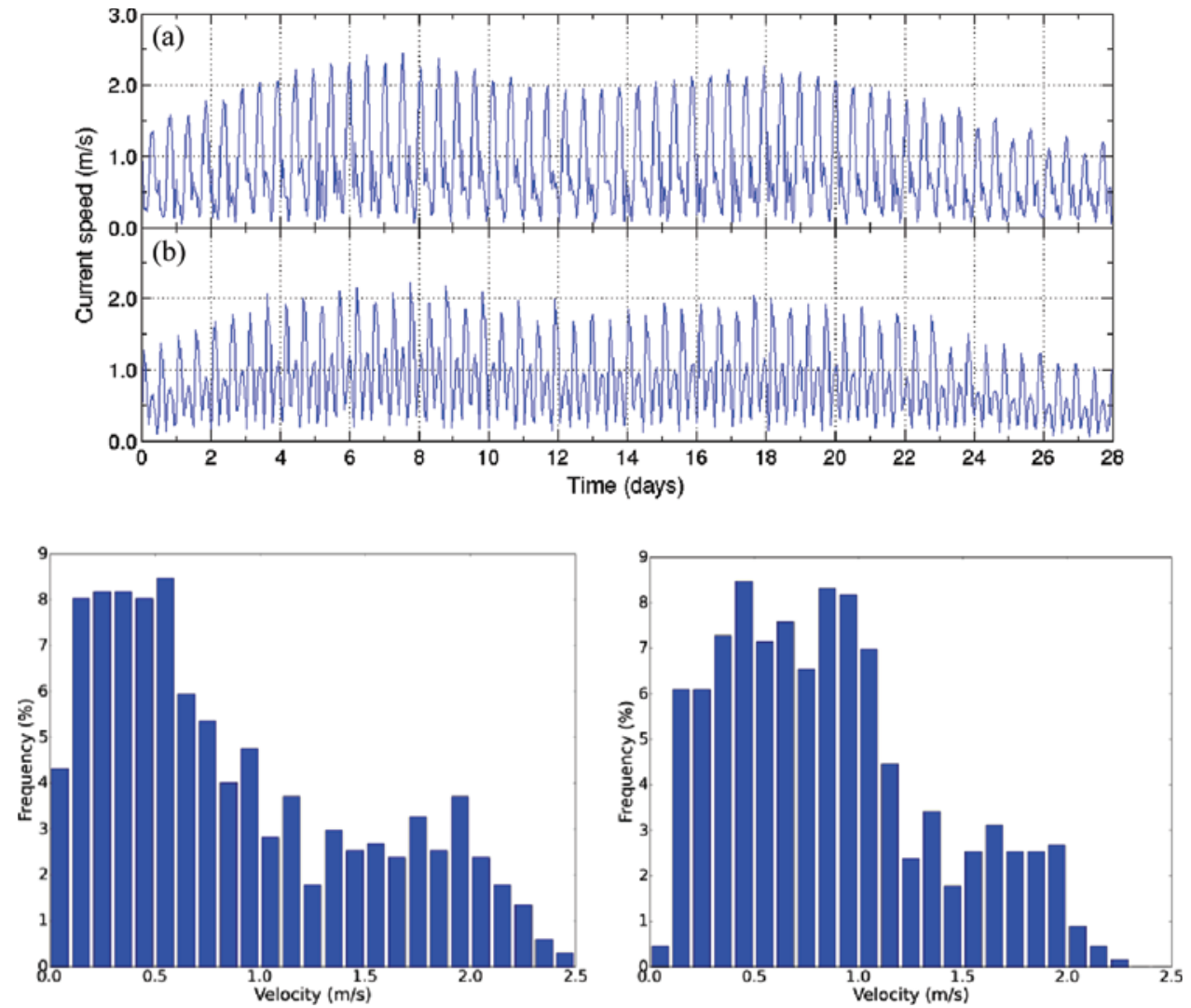

By substituting $V$ in equation (3) with the current speed limit of $1 \mathrm{~m} / \mathrm{s}$ given by Myers and Bahaj (2005), the minimum available APD that allows a site to be worth exploiting from an energetic point of view can be defined. In the ría de Vigo region, this threshold is exceeded in an area extending over $7.5 \mathrm{~km}^{2}$, in the northern channel (Figure 7). Therefore, from an exergetic perspective, this entire region is a potentially suitable site 
for the installation of TECs (in particular around points PF and PM), with a total APD of $296.24 \mathrm{~kW} / \mathrm{m}^{2}$, which represents an annual energetic potential of $3864.34 \mathrm{MWh} / \mathrm{m}^{2}$. The feasibility of the development of TEC plants, however, will depend also on other factors such as the local water depth or the easiness of the plant connection with the main electrical grid.

Figure 4 Power density in the domain at mid-flood (top) and mid-ebb (bottom) during a spring tide. PF and PE show the positions at which the current speed is maximum at mid-flood and mid-ebb, respectively (see online version for colours)
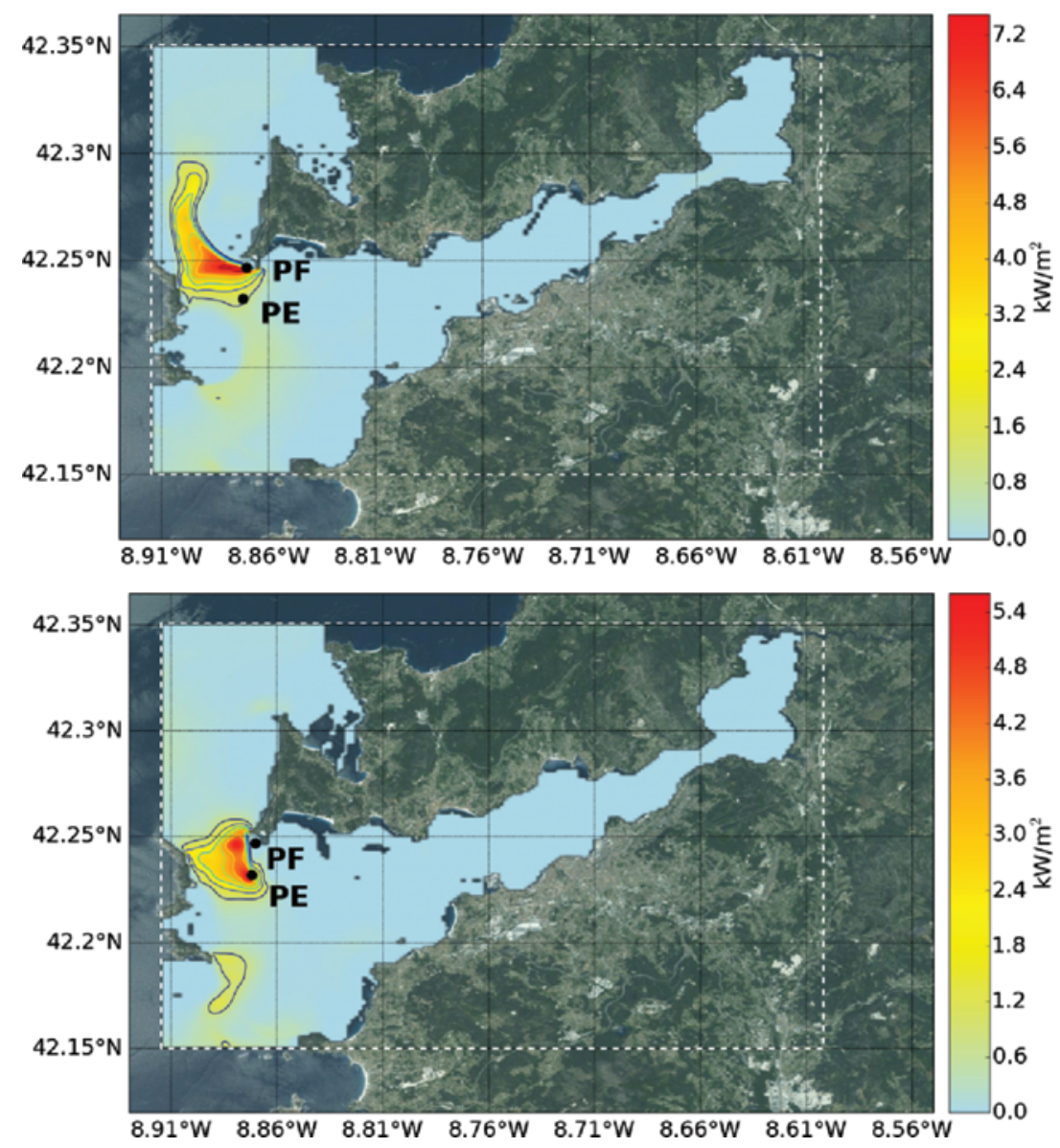

Finally, the influence of the time window used to estimate the tidal stream resource has been assessed by comparing the results obtained with the full 28-day long data series with those found using only a spring-neap tidal cycle (14 days). For this, the time series has been split into two, corresponding to the perigean (spring-neap cycle with larger amplitudes) and apogean phases. The comparison, both for points PF, PE and PM, and for the selected region depicted in Figure 7, is given in Table 1, and shows results compatible with those presented in Byun et al. (2013). Estimates calculated during the perigean cycle are between $15 \%$ and $17 \%$ higher than those using the full lunar month, whereas they are smaller during the apogean cycle in approximately the same percentage. 
Figure 5 Average power density in the domain at mid-flood (top) and mid-ebb (bottom) during a spring tide. PF and PE show the positions at which the current speed is maximum at mid-flood and mid-ebb, respectively (see online version for colours)

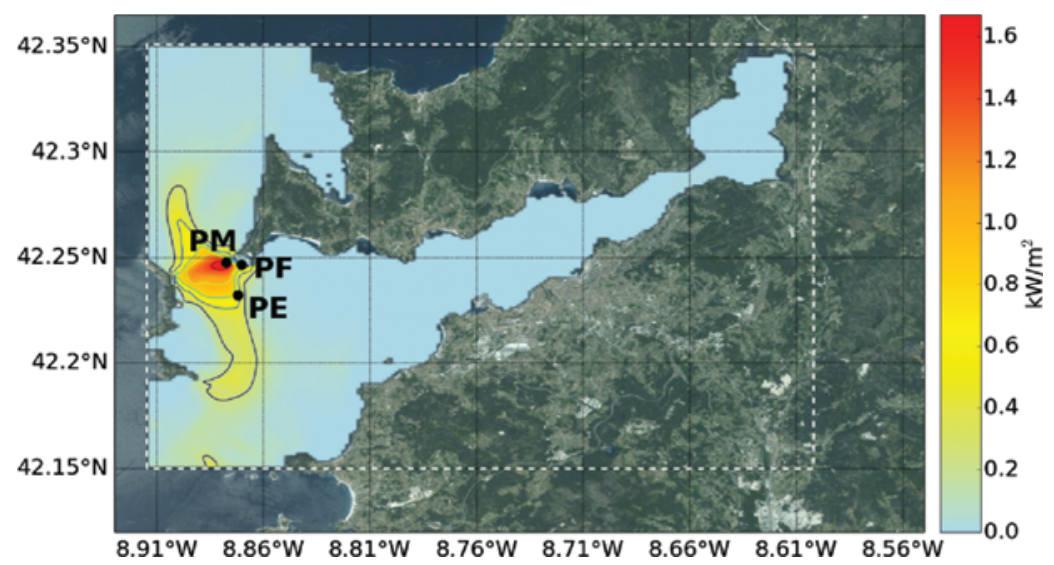

Figure 6 Power density at PF (a) and PE (b) during the simulated 28-day period. The red line shows the average power density at each position (APD) (see online version for colours)

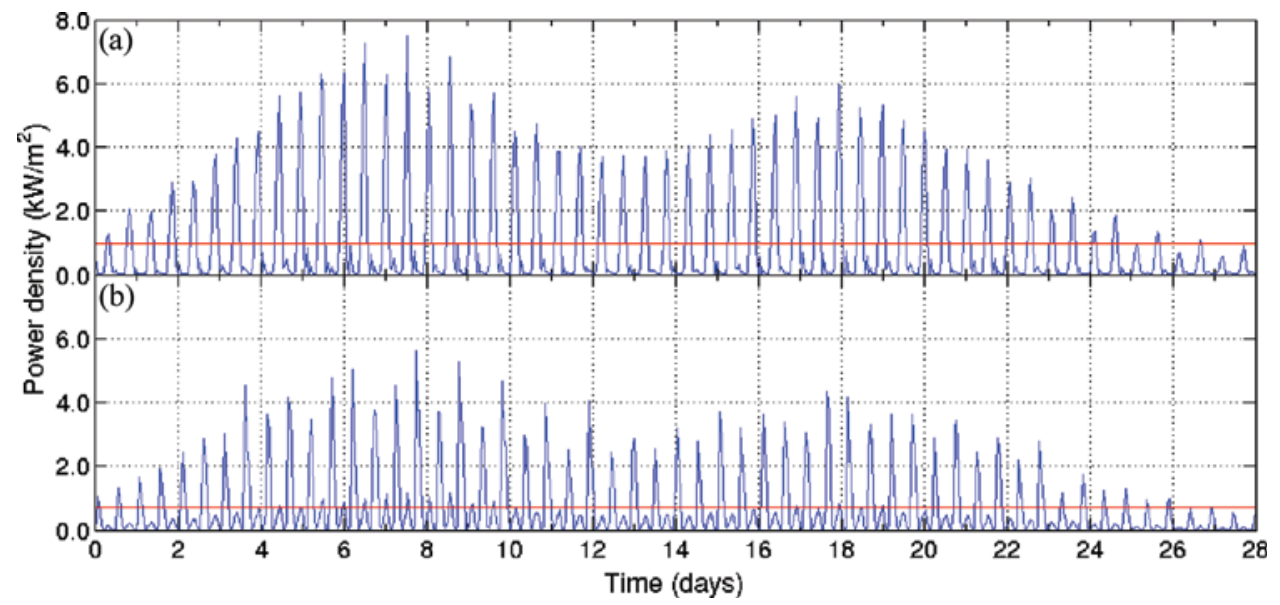

Table 1 Annual energy density estimated using the data for the complete 28-day lunar month, and the apogean and perigean 14-day cycles. Numbers in italics denote difference (\%) with respect to the lunar month estimates

\begin{tabular}{|c|c|c|c|c|c|c|c|c|c|}
\hline & \multicolumn{3}{|c|}{$\begin{array}{l}\text { Lunar month } \\
(28 \text { days })\end{array}$} & \multicolumn{3}{|c|}{$\begin{array}{c}\text { Apogean cycle } \\
(14 \text { days })\end{array}$} & \multicolumn{3}{|c|}{$\begin{array}{c}\text { Perigean cycle } \\
(14 \text { days })\end{array}$} \\
\hline & $P F$ & $P E$ & $P M$ & $P F$ & $P E$ & $P M$ & $P F$ & $P E$ & $P M$ \\
\hline $\begin{array}{l}\text { Annual } \\
M W h / m^{2}\end{array}$ & 8.44 & 6.24 & 14.66 & $\begin{array}{c}7.08 \\
(-16.1)\end{array}$ & $\begin{array}{c}5.22 \\
(-16.3)\end{array}$ & $\begin{array}{c}12.44 \\
(-15.1)\end{array}$ & $\begin{array}{c}9.81 \\
(16.3)\end{array}$ & $\begin{array}{c}7.27 \\
(16.4)\end{array}$ & $\begin{array}{l}16.88 \\
(15.1)\end{array}$ \\
\hline $\begin{array}{l}\text { Annual } \\
M W h / m^{2} \text { in } \\
\text { the selected } \\
\text { area }\end{array}$ & \multicolumn{3}{|c|}{3864.34} & \multicolumn{3}{|c|}{$\begin{array}{l}3220.56 \\
(-16.6)\end{array}$} & \multicolumn{3}{|c|}{$\begin{array}{c}4513.85 .3 \\
(16.8)\end{array}$} \\
\hline
\end{tabular}


Figure 7 Area in which the available APD exceeds the threshold for viable exploitation of tidal stream resource (see online version for colours)

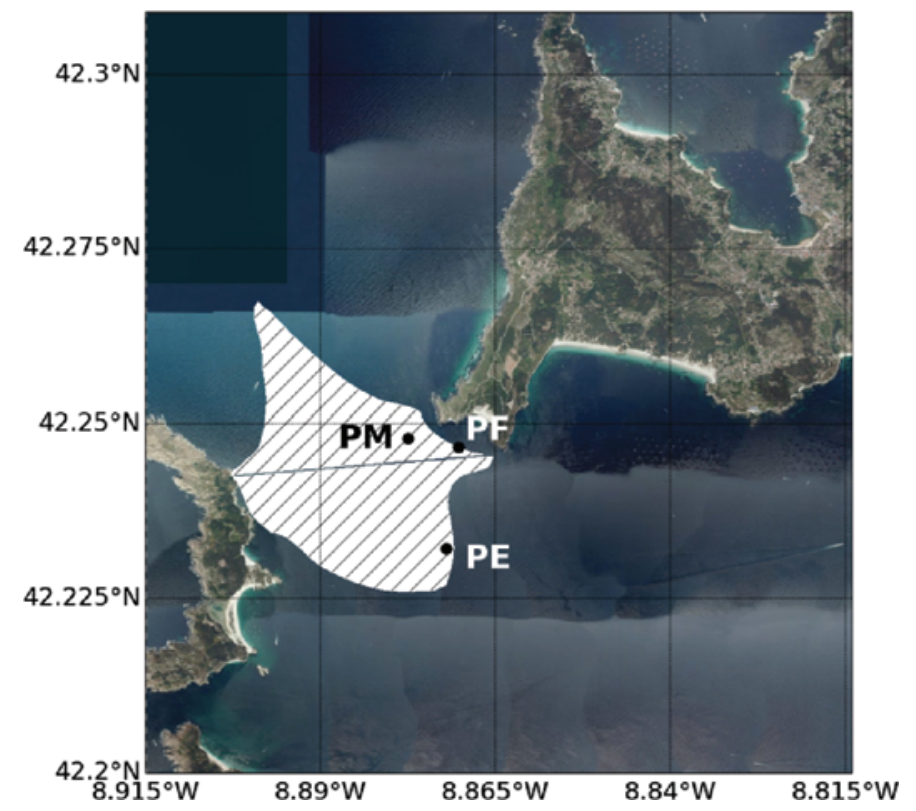

\section{Conclusions}

The extraction of tidal current energy, which harnesses the kinetic energy contained in the tidal streams, is emerging as a great potential source of renewable and clean energy. It has a number of advantages with regard to other renewable energies, such as the resource predictability, the minimal visual impact and land occupation, its high load factor or its sustainability.

Owing to its morphological characteristics and its relatively large tidal range, the ría de Vigo, a large coastal embayment located in the north-west of Spain, seems to be an attractive location for evaluating the capability of tidal current power production. To confirm this, its potential has been assessed by simulating the hydrodynamics within and around the estuary using a 3D numerical code. The simulated period has been one full lunar cycle, in order to reproduce the natural monthly variation of the tides. The validation of the numerical code in this area has been presented in Cerralbo et al. (2013).

The results indicate that there is sufficient tidal exergy in the northernmost channel that connects the ría de Vigo to the Atlantic Ocean, although the estuary itself is not suitable for the development of viable tidal stream power extraction. In this strait, between the Illa Norte and the peninsula, maximum current speeds of around $2.5 \mathrm{~m} / \mathrm{s}$ are attained at mid-flood of the spring tide, as compared to velocities of the order of $1 \mathrm{~m} / \mathrm{s}$ at some locations inside the estuary. During ebb tide, the maximum velocities are somewhat lower, but remain above $2 \mathrm{~m} / \mathrm{s}$ in the channel. The maximum available power density is about $7.5 \mathrm{~kW} / \mathrm{m}^{2}$ at mid-flood of the spring tide, decreasing to $5.6 \mathrm{~kW} / \mathrm{m}^{2}$ at mid-ebb. The maximum APD is $1.67 \mathrm{~kW} / \mathrm{m}^{2}$, larger than that observed at other study sites. On the basis of the distribution of tidal currents, the region susceptible of being exploited for 
tidal stream energy extends over a $7.5 \mathrm{~km}^{2}$ area in the northern channel, with an available exergy of around $3865 \mathrm{MWh} / \mathrm{m}^{2}$ per annum. The analysis also highlights the differences in the estimated tidal stream exergy incurred when a spring-neap tidal cycle is used instead of a full lunar month period. Although the former is common practice in the assessment of tidal stream energy potential, it can under- or overestimate the resource by as much as $16 \%$.

In spite of these analyses, it should be stressed that the final development of any TEC plants will depend also on a number of different physical, environmental, technological and economic factors that have to be taken into account, such as the local water depth, the ecological susceptibility of the area, or the existing TEC efficiency, among others.

\section{Acknowledgements}

This study was funded by the research project "Desarrollo de una herramienta de alta resolución como soporte al diseño, colocación y explotación de instalaciones para energías marinas (DARDO)" (Ref. ENE2012-38772-C02-02) funded by the Spanish Ministry of Economy and Competitiveness. The support of the Secretaria d'Universitats i Recerca of the Dpt. d'Economia i Coneixement de la Generalitat de Catalunya (Ref. 2014SGR1253) is also acknowledged.

\section{References}

Álvarez, I., deCastro, M., Gómez-Gesteira, M. and Prego, R. (2005) 'Inter- and intra-annual variability of the salinity and temperature evolution in the Galician rías Baixas - ocean boundary (northwest Spain)', Journal of Geophysical Research, Vol. 110, No. C04008, pp.1-14, DOI: 10.1029/2004JC002504.

APPA (2015) Study of the Macroeconomic Impact of Renewable Energies in Spain, http://www.appa.es/descargas/estudio_APPA_ENG_14_Web.pdf (Accessed 21 April, 2016).

APPA (2016) Energy in Spain, http://www.appa.es/index.php (Accessed 21 April, 2016) (in Spanish).

Bahaj, S., Molland, A.F., Chaplin, J.R. and Batten, W.M.J. (2007) 'Power and thrust measurements of marine current turbines under various hydrodynamic flow conditions in a cavitation tunnel and a towing tank', Renewable Energy, Vol. 32, No. 3, pp.407-426, DOI: 10.1016/j.renene.2006.01.012.

Batten, W.M.J., Bahaj, A.S., Molland, A.F. and Chaplin, J.R. (2007) 'Experimentally validated numerical method for the hydrodynamic design of horizontal axis tidal turbines', Ocean Engineering, Vol. 34, No. 7, pp.1013-1020, DOI: 10.1016/ j.oceaneng.2006.04.008.

Blunden, L.S. and Bahaj, A.S. (2007) 'Tidal energy resource assessment for tidal stream generators', Proceedings of the Institution of Mechanical Engineers, Part A: Journal of Power and Energy, Vol. 221, pp.137-146, DOI: 10.1243/09576509JPE332.

Brooks, D. (2011) 'The hydrokinetic power resource in a tidal estuary: the Kennebec River of the central Maine coast', Renewable Energy, Vol. 36, pp.1492-1501, DOI: 10.1016/ j.renene.2010.10.029.

Bryden, I.G., Couch, S.J., Owen, A. and Melville, G. (2007) 'Tidal current resource assessment', Proceedings of the Institution of Mechanical Engineers, Part A: Journal of Power and Energy, Vol. 221, No. 2, pp.125-135, DOI: 10.1243/09576509JPE238.

Byun, D.S., Hart, D.E. and Jeong, W.J. (2013) 'Tidal current energy resources off the south and west coasts of Korea: preliminary observation-derives estimates', Energies, Vol. 6, No. 2, pp.566-578, DOI: 10.3390/en6020566. 
Carballo, R., Iglesias, G. and Castro, A. (2009) 'Numerical model evaluation of tidal stream energy resources in the ría de Muros (NW Spain)', Renewable Energy, Vol. 34, No. 6, pp.1517-1524, DOI: $10.1016 /$ j.renene.2008.10.028.

Cerralbo, P., Grifoll, M., Espino, M. and López, J. (2013) 'Predictability of currents on a mesotidal estuary (ría de Vigo, NW Iberia)', Ocean Dynamics, Vol. 63, Nos. 2-3, pp.131-141, DOI: $10.1007 / \mathrm{s} 10236-012-0586-9$.

Dincer, I. and Rosen, M. (2007) Exergy. Energy, Environment and Sustainable Development, Elsevier Ltd., Oxford, UK.

Draper, S., Adcock, T., Bothwick, A., and Houlsby, G. (2014) 'Estimate of the tidal stream power resource of the Pentland Firth', Renewable Energy, Vol. 63, pp.650-657, DOI: 10.1016/ j.renene.2013.10.015.

Edalati, S., Ameri, M., Iranmanesh, M. and Tarmahi, H. (2016) 'Modelling and drawing energy and exergy of solar radiation', International Journal of Exergy, Vol. 19, No. 4, pp.544-568, DOI: 10.1504/IJEX.2016.075890.

Egbert, G.D. and Erofeeva, S.Y. (2002) 'Efficient inverse modelling of barotropic ocean tides', Journal of Atmospheric and Oceanic Technology, Vol. 19, pp.183-204, DOI: 10.1175/ 1520-0426(2002)019<0183:EIMOBO>2.0.CO;2.

Grabbe, M., Lalander, E., Lundin, S. and Leijon, M. (2009) 'A review of the tidal current resource in Norway', Renewable and Sustainable Energy Reviews, Vol. 13, No. 8, pp.1898-1909, DOI: 10.1016/j.rser.2009.01.026.

Haidvogel, D.B., Arango, H., Budgell, W.P., Cornuelle, B.D., Curchitser, E., Di Lorenzo, E., Fennel, K., Geyer, W.R., Hermann, A.J., Lanerolle, L., Levin, J., McWilliams, J.C., Miller, A.J., Moore, A.M., Powell, T.M., Shchepetkin, A.F., Sherwood, C.R., Signell, R.P., Warner, J.C. and Wilkin, J. (2008) 'Ocean forecasting in terrain-following coordinates: Formulation and skill assessment of the Regional Ocean Modeling System', Journal of Computational Physics, Vol. 227, pp.3595-3624, DOI: 10.1016/j.jcp.2007.06.016.

Hogerwaard, J. and Dincer, I. (2014) 'Energy and exergy analyses of a combined multigeneration system', in Dincer, I., Midilli, A. and Kucuk, H. (Eds.): Progress in Exergy, Energy, and the Environment, Springer Int. Pub., New York, USA, pp.133-143.

Iglesias, G. and Carballo, R. (2005) 'Wave energy resource in the Estaca de Bares area (Spain)', Renewable Energy, Vol. 35, pp.1574-1584, DOI: 10.1016/j.renene.2009.10.019.

Iglesias, G., Sánchez, M., Carballo, R. and Fernández, H. (2012) 'The TSE index - a new tool for selecting tidal stream sites in depth-limited regions', Renewable Energy, Vol. 48, pp.350-357, DOI: 10.1016/j.renene.2012.05.012.

Karsten, R.H., McMillan, J.M., Lickley, M.J. and Haynes, R.D. (2008) 'Assessment of tidal current energy in the Minas passage, Bay of Fundy', Proceedings of the Institution of Mechanical Engineers, Part A: Journal of Power and Energy, Vol. 222, No. 5, pp.493-507, DOI: 10.1243/09576509JPE555.

Kim, C.S. and Lim, H-S. (2009) 'Sediment dispersal and deposition due to sand mining in the coastal waters of Korea', Continental Shelf Research, Vol. 29, No. 1, pp.194-204, DOI: $10.1016 /$ j.csr.2008.01.017.

Kurtgoz, Y. and Deniz, E. (2016) 'Global solar radiation estimation using artificial neural network by the addition of nearby meteorological stations' solar radiation data and exergy of solar radiation: a case study', International Journal of Exergy, Vol. 21, No. 3, pp.315-330, DOI: 10.1504/IJEX.2016.079309.

Large, W.C., McWilliams, J.C. and Doney, S.C. (1994) 'Oceanic vertical mixing: a review and a model with a nonlocal boundary layer parameterization', Reviews Geophysics, Vol. 32, pp.363-403, DOI: 10.1029/94RG01872.

Lefevre, F., Lyard, F.H. and Le Provost, C. (2002) 'FES99: a global tide finite element solution assimilating tide gauge and altimetric information', Journal of Atmospheric and Oceanic Technology, Vol. 19, No. 9, pp.1345-1356, DOI: 10.1175/1520-0426(2002) 019<1345:FAGTFE $>2.0 . \mathrm{CO} ; 2$. 
Li, D., Wang, S. and Yuan, P. (2010) 'An overview of development of tidal current in China: energy resource conversion technology and opportunities', Renewable and Sustainable Energy Reviews, Vol. 14, pp.2896-2905, DOI: 0.1016/j.rser.2010.06.001.

Liberti, L., Carillo, A. and Sannino, G. (2013) 'Wave energy resource assessment in the Mediterranean, the Italian perspective', Renewable Energy, Vol. 50, pp.938-949, DOI: $10.1016 /$ j.renene.2012.08.023.

Martín, B. (2003) Dynamic description of the circulation in two rias baixas: Vigo and Pontevedra, $\mathrm{PhD}$ thesis, University of Vigo, Vigo, Spain (in Spanish).

Mestres, M. and Sierra, J.P. (2011) Meteorological and oceanographic characterization of the ria de Vigo, Research Report RR-LIM/AHC-11-1, UPC-BarcelonaTech, Barcelona, Spain.

Mestres, M., Griñó, M., Sierra, J.P. and Mösso, C. (2016) 'Analysis of the optimal deployment location for tidal energy converters in the mesotidal Ria de Vigo (NW Spain)', Energy, Vol. 115, pp.1179-1187, DOI: 10.1016/j.energy.2016.06.055.

Mestres, M., Sierra, J.P., Mösso, C. and Sánchez-Arcilla, A. (2010) 'Sources of contamination and modelled pollutant trajectories in a Mediterranean harbour (Tarragona, Spain)', Marine Pollution Bulletin, Vol. 60, pp.898-907, DOI: 10.1016/j.marpolbul.2010.01.002.

Mestres, M., Sierra, J.P., Mösso, C., Sánchez-Arcilla, A., Hernáez, M. and Morales, J. (2014) 'Numerical assessment of the dispersion of overspilled sediment from a dredge barge and its sensitivity to various parameters', Marine Pollution Bulletin, Vol. 79, Nos. 1-2, pp.225-235, DOI: 10.1016/j.marpolbul.2013.12.009.

Miguel, A.F. and Aydin, M. (2012) 'Ocean energy and energy conversion systems', International Journal of Exergy, Vol. 10, No. 4, pp.454-470, DOI: 10.1504/ IJEX.2012.047507.

MINETUR (Ministry of Industry, Energy and Tourism) (2014) Energy in Spain 2013, http:// www.minetur.gob.es/energia/balances/Balances/LibrosEnergia/Energia en espana_2013.pdf (Accessed 28 October, 2015) (in Spanish).

Montero, P. (1999) Hydrodynamic study of the ría de Vigo using a finite volumes model, $\mathrm{PhD}$ thesis, University of Santiago de Compostela, Santiago de Compostela, Spain (in Spanish).

Mösso, C., Mestres, M., Sierra, J.P., González-Marco, D. and Barbusca, L. (2015) 'Evaluation of wave and tidal stream resources in Bilbao (N Spain)', EWTEC 2015, Proceedings 11th EWTEC Conference, Nantes, France, paper 07P2-1, pp.1-8.

Mousavi, G. (2012) 'An autonomous hybrid energy system of wind/tidal/microturbine/battery storage', International Journal of Electrical Power \& Energy Systems, Vol. 43, No. 1, pp.1144-1154, DOI: 10.1016/j.ijepes.2012.05.060.

Myers, L. and Bahaj, A.S. (2005) 'Simulated electrical power potential harnessed by marine current turbine arrays in the Alderney Race', Renewable Energy, Vol. 30, No. 11, pp.1713-1731, DOI: $10.1016 /$ j.renene.2005.02.008.

Nogueira, E., Pérez, F.F. and Ríos, A.F. (1997) 'Seasonal patterns and long-term trends in an estuarine upwelling ecosystem (ría de Vigo, NW Spain)', Estuarine, Coastal and Shelf Science, Vol. 44, pp.285-300, DOI: 10.1006/ecss.1996.0119.

O'Rourke, F., Boyle, F. and Reynolds, A. (2010) 'Tidal energy update 2009', Applied Energy, Vol. 87, No. 2, pp.398-409, DOI: 10.1016/j.apenergy.2009.08.014.

Öztürk, M. (2011) 'Energy and exergy assessments for potential wind power in Turkey', International Journal of Exergy, Vol. 8, No. 11, pp.211-226, DOI: 10.1504/ IJEX.2011.038519.

Penven, P., Debreu, L., Marchesiello, P. and McWilliams, J.C. (2006) 'Evaluation and application of the ROMS 1-way embedding procedure to the central California upwelling system', Ocean Modelling, Vol. 12, pp.157-187, DOI: 10.1016/j.ocemod.2005.05.002.

Penven, P., Marchesiello, P., Debreu, L. and Lefevre, J. (2007) 'Software tools for pre- and postprocessing of oceanic regional simulations', Environmental Modelling and Software, Vol. 23, pp.660-662, DOI: 10.1016/j.envsoft.2007.07.004. 
Piedracoba, S., Rosón, G. and Varela, R.A. (2016) 'Origin and development of recurrent dipolar vorticity structures in the outer Ría de Vigo (NW Spain)', Continental Shelf Research, Vol. 118, pp.1143-1153, DOI: 10.1016/j.csr.2016.03.001.

Rashid, A. (2012) 'Status and potentials of tidal in-stream energy resources in the southern coasts of Iran: a case study', Renewable and Sustainable Energy Reviews, Vol. 16, pp.6668-6677, DOI: 0.1016/j.rser.2012.08.010.

Sahin, A., Dincer, I. and Rosen, M. (2006) 'Thermodynamic analysis of wind energy', International Journal of Energy Research, Vol. 30, pp.553-566, DOI: 10.1002/er.1163.

Shchepetkin, A.F. and McWilliams, J.C. (2005) 'The regional oceanic modeling system (ROMS): a split-explicit, free-surface, topography-following-coordinate oceanic model', Ocean Modelling, Vol. 9, No. 4, pp.347-404, DOI: 10.1016/j.ocemod.2004.08.002.

Sierra, J.P., González-Marco, D., Sospedra, J., Gironella, X., Mösso, C. and Sánchez-Arcilla, A. (2013) 'Wave energy resource assessment in Lanzarote (Spain)', Renewable Energy, Vol. 55, pp.480-489, DOI: 10.1016/j.renene.2013.01.004.

Song, Y, and Haidvogel, D.B. (1994) 'A semi-implicit ocean circulation model using a generalized topography-following coordinate system', Journal of Computational Physics, Vol. 115, No. 1, pp.228-244, DOI: 10.1006/jcph.1994.1189.

Vennell, R. (2013) 'Exceeding the Betz limit with tidal turbines', Renewable Energy, Vol. 55, pp.277-285, DOI: 10.1016/j.renene.2012.12.016.

Warner, J.C., Geyer, W.R. and Lerczak, J.A. (2005) 'Numerical modeling of an estuary: a comprehensive skill assessment', Journal of Geophysical Research, C: Oceanography, Vol. 110, No. 5, pp.1-13, DOI: 10.1029/2004JC002691.

Xia, J., Falconer, R.A. and Lin, B. (2010) 'Numerical model assessment of tidal stream energy resources in the Severn Estuary, UK', Proceedings of the Institution of Mechanical Engineers, Part A: Journal of Power and Energy, Vol. 224, No. 7, pp.969-983, DOI: 10.1243/09576509JPE938. 